International Journal of Physical Sciences and Engineering
Available online at http://sciencescholar.us/journal/index.php/ijpse
Vol. 3 No. 2, August 2019, pages: $27 \sim 33$
e-ISSN : 2550-6943, p-ISSN : 2550-6951
https://doi.org/10.29332/ijpse.v3n2.326

\title{
The Brain and Its Role on Learning Process
}

\author{
CrossMark

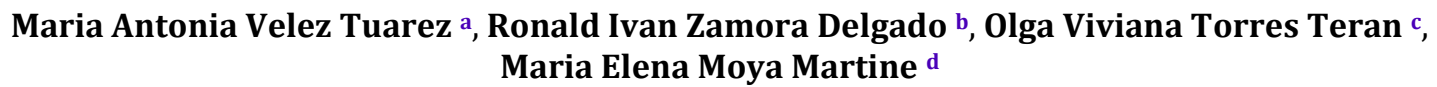

Article history: Received 09 December 2018, Accepted: 30 April 2019, Published: 29 August 2019

\section{Correspondence Author ${ }^{\text {a }}$}

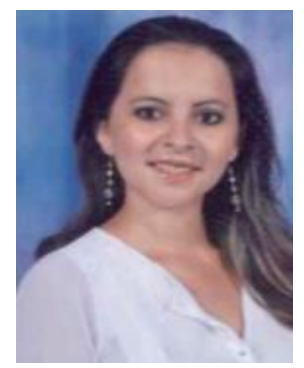

\section{Keywords}

brain;

hemispheres;

human;

learning process;

neuroscience;

\begin{abstract}
This article provided a brief analysis of an important human organ and the influences it has on personal and formal learning in the educational field. The specific topics that were investigated are the brain and its importance in learning, characteristics of the hemispheres of the brain learning and the contribution of neuroscience in the teaching-learning process. The first topic mentions how the brain influences learning and the role of memory in that process. The next topic focuses on the characteristics and functions performed by the two brain hemispheres. The latest content deals with the contribution of neuroscience in the educational field, here is detailed on how neural networks combined with the environment where the student performs to make learning possible. The descriptive methodology, based on the review of current bibliographic sources, was used. The purpose of this document is to provide the reader with true and up-to-date sources of information on an organ that integrates complex and necessary ideas for the human being.
\end{abstract}

e-ISSN: 2550-6943, p-ISSN: 2550-6951 @ Copyright 2019. The Author. SS Journals Published by Universidad Técnica de Manabí. This is an open-access article under the CC BY-SA 4.0 license (https://creativecommons.org/licenses/by-sa/4.0/) All rights reserved.

\section{Contents}

Abstract

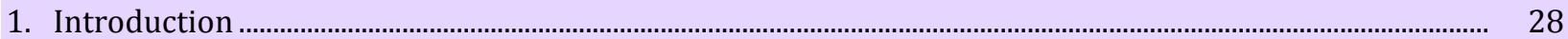

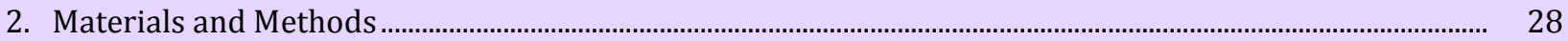

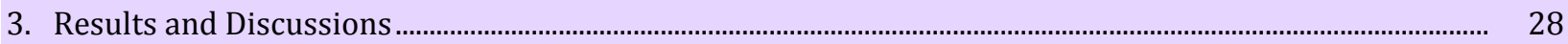

3.1 The brain and its importance in learning ........................................................................................................... 28

3.2 Characteristics of the hemispheres of the brain learning ............................................................................ 29

3.3 The contribution of neuroscience to the teaching-learning process................................................................ 29

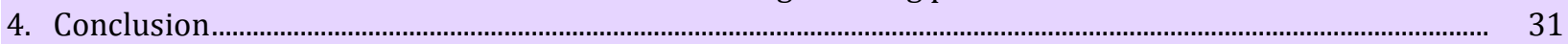

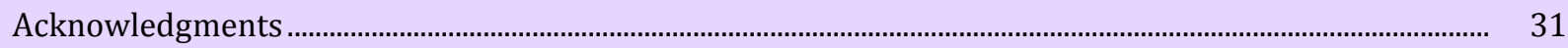

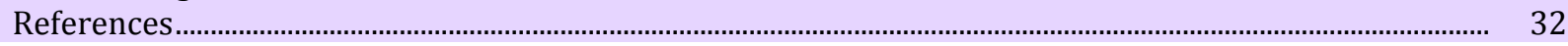

a Pontificia Universidad Católica del Ecuador, Sede Manabí, Portoviejo, Ecuador

b Pontificia Universidad Católica del Ecuador, Sede Manabí, Portoviejo, Ecuador

c Pontificia Universidad Católica del Ecuador, Sede Manabí, Portoviejo, Ecuador

d Pontificia Universidad Católica del Ecuador, Sede Manabí, Portoviejo, Ecuador 


\section{Introduction}

The brain is a complex organ that has the human being, is the engine that controls and regulates all motor, sensitive and integrative activities or functions of the body of the individual. It is important to know that this small organ is responsible for each and every activity, behavior and actions that man executes, he argues (Velasquez et al., 2009), the brain of man is the organ responsible for all processes that lead to imagination, thought, intuition, consciousness, and a number of human-specific behaviors.

The brain is like the wheel of a ship's rudder because it is responsible for controlling and correctly directing the movements of the body, an injury or the improper development of this organ can cause severe and irremediable consequences in the good sense and motor functioning of the organism.

The learning processes described above are produced by an interneuronal connection called synapses, this interconnection of neurons allows the brain to receive internal and external stimuli from the environment in which it is developed, turning it into a processor of information, leading to learning.

Emotions play an essential role in the learning process, in addition to the cognitive part, the emotional state of the individual has a lot of influence on learning. Cognitive and emotional aspects should not be considered separately (García, 2012), because both lead to the integral development of the individual.

\section{Materials and Methods}

This article has used the dissertation that applies the descriptive methodology, with the analysis and synthesis of contents of an updated bibliographic review with different sources based on specialized literature.

\section{Results and Discussions}

\subsection{The brain and its importance in learning}

The importance of the brain lies in the simple thinking where it is located, that is, this organ unlike other internal parts of the body is covered by resistant bones that jealously protect it from any external injury. The central nervous system, particularly the brain, has an infinite learning capacity due to the enormous flexibility by the 100 billion neurons that connect (synapses) to produce the acquisition of knowledge. Brain flexibility is caused by the brain's ability to plasticity (Dzib, 2013a), which uses the subject to learn and adapt easily.

The learning is carried out by the intervention of various cognitive processes that make possible the acquisition of knowledge and experiences that are captured by the sensory organs, and that occurs in the social-cultural context where the Individual. This knowledge is captured, coded, interpreted, processed, and used when the situation, so warrants (Macías et al., 2018; Mendoza et al., 2019).

Learning can be given through external stimuli that are perceived by the body's sensory organs and then transform into perceptions. This learning takes place throughout the individual's life process, in which a permanent behavior change occurs due to the stimuli received from the environment.

Memory cannot go unnoticed if we talk about learning itself. Learning and memory are two cognitive processes that are intimately related and indispensable for the development and subsistence of the human being in the environment around him.

Memory is the place where all events, knowledge, facts, and concepts that are evoked at any time are stored and internalized to give them the necessary use. The information acquired and stored in the neural circuits of the brain, this process, is called memory. The memorization process occurs after learning. These two elements cannot be treated separately.

In this subject, the plasticity of the brain plays an indispensable role because it allows the individual to acquire, and sometimes memorize indefinitely the information of the environment. Learning and memory are 
elements that contribute to plasticity, and the more plastic the brain of the individual is the greater the ability to acquire knowledge (Olivares et al., 2015).

It is necessary to mention the two known memory types: implicit and explicit. There are other types of memory that are part of storage differently, but this article will cover the two mentioned in this paragraph because it relates directly to the learning that bears the same name.

Implicit memory occurs from spontaneous learning, that is, the individual is not even aware that he is learning. From a psychological perspective, according to Heads (2015), implicit memory relates to learning to acquire knowledge, motor skills, and behaviors with a range of coding and unconscious storage.

Explicit memory is based on conscious learning because the individual knows that the act of learning is being aroused. This memory stores information deliberately and consciously about the lived experiences of the individual in the place where he performs (Pérez et al., 2016). The environment surrounding the individual plays an indispensable role in the processing of information.

\subsection{Characteristics of the hemispheres of the brain learning}

In the brain's anatomy, it can be observed that it has two hemispheres, left and right, which are bound by fibers containing millions of nerve cells that control mental processes. These have some particularity when controlling the functions of the body, i.e. the left hemisphere coordinates the right side of the body and vice versa.

Each hemisphere performs specific functions (Muñoz et al., 2012), the left side relates to speech production, analytical ability and logical reasoning, numerical calculations, while the right side is responsible for control nonverbal aspects, spatial orientation of images, ability to express and capture emotions, developed capacity of intuition, among others.

Figure 1 shows the main functions or characteristics of each of these hemispheres.

\section{LEFT HEMISPHERE}

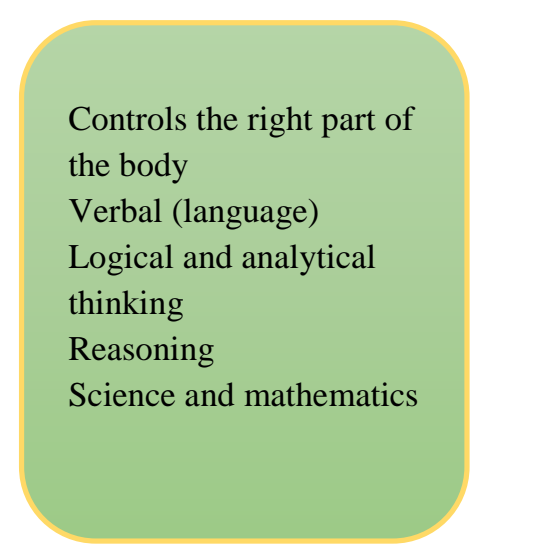

\section{RIGHT HEMISPHERE}

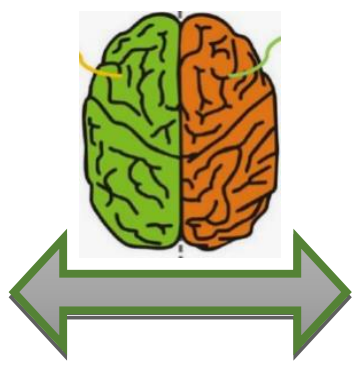

Controls the left part of the body

Nonverbal (creativity)

Holistic and synthetic

thinking

Intuitive

Art and music

Figure 1. Functions of the left and right hemisphere

\subsection{The contribution of neuroscience to the teaching-learning process}

For a long time, the educational process was regarded as a system in which the development of intellectual skills was given importance and a homogeneous method of teaching was used, but the contribution of neuroscience in education has given a new meaning to this problem. Significant contributions of neuroscience have helped to understand that knowing how the brain works lead to changing pedagogical practice and improving educational quality (Gago \& Elgier, 2018).

Tuarez, M. A. V., Delgado, R. I. Z., Teran, O. V. T., \& Martine, M. E. M. (2019). The brain and its role on learning process. International Journal of Physical Sciences and Engineering, 3(2), 27-33.

https://doi.org/10.29332/ijpse.v3n2.326 
Understanding learning as a continuous, permanent process of behavioral changes due to the perceived stimuli of the environment and not as a mere acquisition of knowledge-oriented to the intellectual development of the individual, leads to the idea that the brain is the fundamental pillar for the subject to form in an integral way.

The study of neuroscience argues that the development of the capacities and behavioral change of the human being occurs by the neural connections caused by the different stimuli received from the environment. Neuroscience argues that the behavior of the individual depends on the connection of neural networks (Dzib, 2013b), which is related to the place where the brain develops and the stimulation it receives from it. From this perspective, the environment takes an important role in the human learning process.

Man is a unique and incomparable being, people's brain structures are different from each other. Each individual perceives, interprets, encodes and analyzes the world from different points of view, in such a way that one cannot pretend to teach in a homogeneous way to all (Suarez et al., 2019; Alava \& Martinez, 2019).

In the educational process, teachers need to know how the brain works to provide their educators with proper education. Neuroscience can make a significant contribution to the teaching-learning process (Alvarez, 2013) because as the teacher begins to understand the structure and functioning of the brain, he will be able to learn to teach and adjust methods and pedagogical strategies according to the different needs of the educated.

The study of the brain and the influence it has on the learning process is a topic that generates great expectations and uncertainty in researchers, neuroscientists, and teachers because it seems essential to know the functioning of the motor that governs human behavior and action. Table 1 shows a brief description of the valuable contribution of some authors with respect to related topics on functions and characteristics of the brain, memory and their role in learning, contributions of neuroscience in the process of teaching-learning, among others.

Table 1

Analysis of authors' approaches

\begin{tabular}{|c|c|c|c|}
\hline $\begin{array}{l}\text { Author / } \\
\text { Authors }\end{array}$ & Year & Document title & Interpretation of the theme \\
\hline $\begin{array}{l}\text { Dzib Goodin } \\
\text { Alma }\end{array}$ & $2013 a$ & $\begin{array}{l}\text { The evolution of learning: } \\
\text { beyond neural networks }\end{array}$ & $\begin{array}{l}\text { Brain flexibility is produced by the ability of } \\
\text { plasticity that the brain possesses, and } \\
\text { thanks to such plasticity the subject has the } \\
\text { possibility to learn and adapt with ease. }\end{array}$ \\
\hline $\begin{array}{l}\text { Olivares, } \\
\text { Juárez \& } \\
\text { García }\end{array}$ & 2015 & $\begin{array}{l}\text { Hippocampus: neurogenesis } \\
\text { and learning }\end{array}$ & $\begin{array}{l}\text { Learning and memory are elements that } \\
\text { contribute to plasticity, and the more } \\
\text { plastic the brain of the individual, the } \\
\text { greater the learning capacity }\end{array}$ \\
\hline Cabezas & 2015 & $\begin{array}{l}\text { Non-motor cerebellum } \\
\text { functions and } \\
\text { memoryimplícita: Una } \\
\text { revisión bibliográfica }\end{array}$ & $\begin{array}{l}\text { Implicit memory relates to learning to } \\
\text { acquire knowledge, motor skills, and } \\
\text { behaviors with an unaware scope of coding } \\
\text { and storage. }\end{array}$ \\
\hline $\begin{array}{l}\text { Pérez, } \\
\text { Romero, } \\
\text { Salazar \& } \\
\text { Ortega }\end{array}$ & 2016 & $\begin{array}{l}\text { Pilot study. Implicit memory, } \\
\text { explicit memory, and } \\
\text { cognitive decline: evolution } \\
\text { in psychotic disorder }\end{array}$ & $\begin{array}{l}\text { Explicit memory stores information } \\
\text { deliberately and consciously about the lived } \\
\text { experiences of the individual in the place } \\
\text { where he is unfolded }\end{array}$ \\
\hline $\begin{array}{l}\text { Muñoz, } \\
\text { Gutiérrez \& } \\
\text { Serrano }\end{array}$ & 2012 & $\begin{array}{l}\text { Brain hemispheres, two } \\
\text { thinking styles, two ways to } \\
\text { teach and learn }\end{array}$ & $\begin{array}{l}\text { The left hemisphere relates to speech } \\
\text { production, analytical ability and logical } \\
\text { reasoning, numerical calculations, while the } \\
\text { right hemisphere is responsible for } \\
\text { controlling nonverbal aspects, the spatial } \\
\text { orientation of images, ability to expressing } \\
\text { and capturing emotions, a developed } \\
\text { capacity for intuition, among others. }\end{array}$ \\
\hline
\end{tabular}




\begin{tabular}{|c|c|c|}
\hline $\begin{array}{l}\text { Gago \& } \\
\text { Elgier }\end{array}$ & 2018 & $\begin{array}{l}\text { Building bridges between } \\
\text { neurosciences and } \\
\text { education. Contributions, } \\
\text { limits and future paths in the } \\
\text { educational field }\end{array}$ \\
\hline $\begin{array}{l}\text { Dzib Goodin } \\
\text { Alma }\end{array}$ & $2013 b$ & $\begin{array}{l}\text { Brain architecture as } \\
\text { responsible for the learning } \\
\text { process }\end{array}$ \\
\hline
\end{tabular}

Álvarez $2013 \quad$ Neuroscience in the sciences partner-human: a transdicipliner look
Significant contributions of neuroscience have helped to understand that knowing how the brain works leads to changing pedagogical practice, and thus improving educational quality Neuroscience argues that human behavior depends on the connection of neural networks, which is related to where the brain develops and the stimulation it receives from it.

Neuroscience can make a significant contribution to the teaching-learning process, because to the extent that the teacher begins to understand the structure and functioning of the brain, he will be able to learn to teach and adjust the pedagogical methods and strategies according to the different needs of the students.

Each author has provided interesting and enriching information that leads to a better understanding of the themes raised in this article.

The ability to plasticity (Dzib, 2013a), which has the brain allows the individual to learn and adapt at all times to the environment around him. Memory and learning are two key elements that contribute to this brain plasticity, learning is more optimal the greater the plastic capacity of the brain (Olivares et al., 2015).

Memory is the place where all events are stored and then evoked. According to (Heads, 2016), implicit memory acquires facts and knowledge with a scope of encoding and storage unconsciously. Explicit memory (Pérez et al., 2016), stores information in a deliberate way about the experiences the individual has throughout his life.

The two brain hemispheres have different functions. According to the authors (Muñoz et al., 2012), the left hemisphere is characterized by verbal language, analysis, numerical calculations, logical reasoning; the law focuses on non-verbal aspects, intuition, spatial orientation, musical and artistic ability, among others.

Neuroscience can lead to a significant contribution to the teaching-learning process. The authors Gago \& Elgier (2018), argue that knowing how the brain works lead to the readjustment of pedagogical and educational practice. The knowledge of neuroscience on the part of teachers makes them able to adjust strategies according to the needs of students (Alvarez, 2013).

\section{Conclusion}

It can be concluded that the brain is the key engine for learning and knowledge acquisition to be carried out would not be possible without the participation of this organ, for learning to occur it is necessary for the brain to be stimulated by factors such as the environment.

The contributions of neuroscience in the teaching-learning process promote awareness by teachers in their educational practice, that is, the teacher who is interested in knowing how the brain works of the human being will be able to take as individual differences and learning styles of their students when applying some teaching method or strategy.

\section{Acknowledgments}

A sincere thanks to all the people who participated before and during the preparation of the scientific article. Al. Ronald Iván Zamora, Mr. Olga Viviana Torres, and Mgtr. María Elena Moya who provided valuable information for the editing of the document; To Dr. María Rodríguez Gámez for providing all the guidelines for the proper elaboration of this work and for carrying out the latest revision for its respective shipment.

Tuarez, M. A. V., Delgado, R. I. Z., Teran, O. V. T., \& Martine, M. E. M. (2019). The brain and its role on learning process. International Journal of Physical Sciences and Engineering, 3(2), 27-33. https://doi.org/10.29332/ijpse.v3n2.326 


\section{References}

Alava, E. E., \& Martinez, M. E. M. (2019). Impact of teaching-learning process for brain. International Journal of Health Sciences, 3(1), 33-40. https://doi.org/10.29332/ijhs.v3n1.304

Alma, D. (2013). The cerebral architecture as responsible for the learning process. Rev Mex. Neuroci , 14 (2), 81-85.

Duke, ME. (2013). Neuroscience in the socio-human sciences: a transdisciplinary view. Social Sciences and Education , 2 (3), 153-166.

Gago Galvagno, LG, \& Elgier, Á. M. (2018). Building bridges between neurosciences and education. Contributions, limits and future paths in the educational field. Psychogent, 21 (40), 476-494. http://dx.doi.org/10.17081/psico.21.40.3087

García, R. (2012). La educación emocional, su importancia en el proceso de aprendizaje. Revista Educación, 36 (1), 1-24. https://www.redalyc.org/pdf/440/44023984007.pdf

Goodin, AD (2013). The evolution of learning: beyond neural networks. Chilean Journal of Neuropsychology , 8 (1), 20-25.

Heads, S. W., Huang, Y., ... \& Whiting, M. F. (2015). 300 million years of diversification: elucidating the patterns of orthopteran evolution based on comprehensive taxon and gene sampling. Cladistics, 31(6), 621-651.

Macías, E. I. P., Cedeño, H. A. C., \& Chávez, G. M. R. (2018). Importance of Improving Resilience in TeachingLearning Process of Students with Disabilities. International Research Journal of Management, IT and Social Sciences, 5(2), 120-128.

Mendoza, L. R. M., Martinez, M. E. M., \& Suarez, A. M. S. (2019). The brain as a fundamental axis in learning process. International Research Journal of Engineering, IT \& Scientific Research, 5(4), 38-45. https://doi.org/10.21744/irjeis.v5n4.689

Muñoz González, JM, Gutiérrez-Arenas, MP, \& Serrano Rodríguez, R. (2012). The cerebral hemispheres: two styles of thinking, two ways of teaching and learning.

Olivares, J., Juárez, E., \& García, F. (2015). El hipocampo: neurogénesis y aprendizaje. Rev Med UV, 15(1), 20 28. https://www.medigraphic.com/cgi-bin/new/resumen.cgi?IDARTICULO=61286

Pérez Moreno, JJ, Romero García, M., Salazar Gámez, A., \& Ortega Moreno, B. (2016). Pilot study. Implicit memory, explicit memory and cognitive impairment: evolution in psychotic disorder. Global Nursing , 15 (41), 135-151.

Suarez, A. M. S., Martinez, M. E. M., \& Mendoza, L. R. M. (2019). Brain and learning. International Journal of Social Sciences and Humanities, 3(2), 128-135. https://doi.org/10.29332/ijssh.v3n2.302

Velásquez Burgos, BM, de Cleves, NR, \& Calle Márquez, MG (2009). The Brain That Learns. Rasa tab, (11), 329347. 


\section{Biography of Authors}

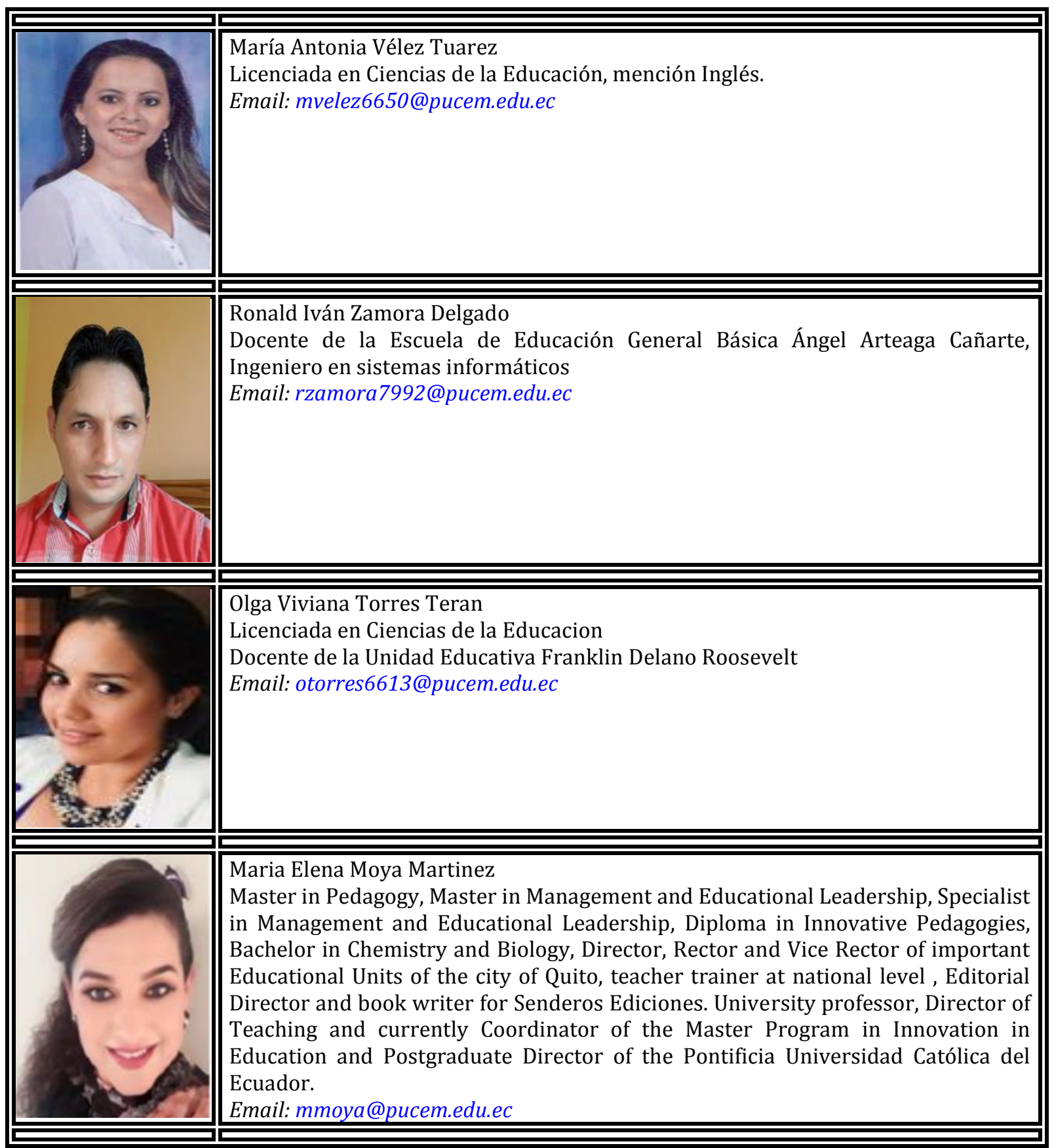

Tuarez, M. A. V., Delgado, R. I. Z., Teran, O. V. T., \& Martine, M. E. M. (2019). The brain and its role on learning process. International Journal of Physical Sciences and Engineering, 3(2), 27-33. https://doi.org/10.29332/ijpse.v3n2.326 